\title{
ASAS ITIKAD BAIK DALAM PERJANJIAN ARBITRASESEBAGAI METODE PENYELESAIAN SENGKETA
}

\author{
Novran Harisa \\ Dosen Universitas Muhammadiyah Bengkulu \\ e-mail: novranharisa@gmail.com
}

\begin{abstract}
Abstrak-Penyelesaian sengketa bisnis melalui arbitrase semakin diminati kalangan dunia usaha karena dianggap mempunyai berbagai kelebihan dibanding penyelesaian melalui pengadilan, terutama putusannya yang bersifat putusan terakhir dan mengikat. Akan tetapi di Indonesia, putusan arbitrase sangat sulit untuk dieksekusi karena adanya upayaupaya yang dilakukan pihak yang tidak beritikad baik untuk membatalkan putusan tersebut melalui permohonan pembatalan kepada pengadilan negeri. Penelitian ini bertujuan untuk merumuskan pengaturan itikad baik dalam perjanjian arbitrase dihubungkan dengan arbitrase sebagai metode penyelesaian sengketa. Hasil penelitian menunjukkan bahwa Pengaturan itikad baik dalam Undang-Undang Nomor 30 tahun 1999 tentang Arbitrase dan Alternatif Penyelesaian Sengketa belum memberi pemahaman tentang makna dan batasan itikad baik. Pengaturan itikad baik sebaiknya dirumuskan sebagai "sikap atau perilaku berpegang teguh pada perjanjian untuk memberikan kepada lawan janji apa yang menjadi haknya dan tidak mencari-cari celah untuk melepaskan diri dari apa yang telah diperjanjikan berdasarkan kepatutan dan kerasionalan.
\end{abstract}

\section{Kata Kunci: Itikad Baik, Perjanjian Arbitrase, Penyelesaian Sengketa.}

\begin{abstract}
Settlement of business dispute through arbitration is increasingly in demand among the business community because it is considered to have many advantages over the settlement through the courts, especially its decision which is the final and binding decision. However, in Indonesia, the arbitral award is very difficult to execute because of the efforts made by the parties who have no good intentions to cancel the verdict through the cancellation request to the district court. This study aims to formulate good faith arrangements in arbitration agreements associated with arbitration as a method of dispute settlement. The results showed that good faith arrangement in Law Number 30 of 1999 on Arbitration and Alternative Dispute Settlement has not provided an understanding of the meaning and limits of good faith. The arrangement of good faith should be defined as "the attitude or attitude of sticking to the covenant to give the opponent a promise of what it is entitled to and not looking for a loophole to escape from what has been agreed upon by propriety and rationality.
\end{abstract}

Keywords: Good Faith, Arbitration Agreement, Dispute Settlement.

\section{A. PENDAHULUAN}

Perkembangan perekonomian pada era globalisasi dan modernisasi dewasa ini, menimbulkan pengaruh terhadap berkembangnya transaksi- transaksi bisnis yang melibatkan pihak-pihak tertentu dalam suatu kegiatan perdagangan. Kegiatan perdagangan merupakan salah satu bentuk yang menunjang kegiatan 
perekonomian dalam masyarakat dan juga memiliki peranan yang sangat besar dalam mempengaruhi kondisi perekonomian nasional. Selain itu, perdagangan juga memiliki arti yang sangat penting dalam meningkatkan pertumbuhan ekonomi secara berkesinambungan.

$$
\text { Kegiatan perdagangan }
$$
merupakan salah satu bentuk hubungan hukum perikatan yang lahir karena perjanjian. Perjanjian diawali dengan negosiasi (bargaining process) para pihak sehingga menghasilkan kesepakatan yang tertuang secara tertulis dalam kontrak perdagangan. Kontrak perdagangan dapat dikatakan sah menurut hukum apabila memenuhi syarat sahnya perjanjian yang diatur dalam Pasal 1320 KUHPerdata, yaitu sepakat mereka yang mengikatkan dirinya, cakap untuk membuat suatu perjanjian, suatu hal tertentu dan suatu sebab yang halal (R. Subekti, 2002:15). ${ }^{1}$

Perjanjian atau kontrak berawal dari perbedaan kepentingan yang dipertemukan, selanjutnya dibingkai

1 R. Subekti,Hukum Perjanjian, PT. Intermassa, Jakarta, 2002, hlm. 15 dengan perangkat hukum sehingga mengikat para pihak (Agus Yudha Hernoko, 2008:2). ${ }^{2}$

Konsekuensinya, hukum membiarkan manusia atau individual untuk bebas menentukan apa yang hendak disepakati. Manusia tidak hanya bebas untuk melakukan atau tidak melakukan suatu perbuatan yang dirumuskan oleh undangundang, melainkan dalam arti lebih luas, karena dengan kebebasan itulah ia dapat menentukan pengaturan yang paling baik bagi dirinya (Siti Soemarti Hartono, 1992:22). ${ }^{3}$ Kebebasan berkontrak merupakan "ruh" atau "nafas" dari sebuah perjanjian, yang dilandaskan pada kesadaran bahwa hanya para pihaklah yang mengetahui kebutuhannya untuk melakukan hubungan kontraktual atau perjanjian.

Dalam suatu kontrak perdagangan (bisnis) selalu ada kemungkinan timbulnya konflik atau sengketa yang disebabkan adanya

2 Agus Yudha Hernoko, Hukum Perjanjian: Asas Proporsionalitas dalam Kontrak Komersial, LaksBang Mediatama, Yogyakarta, 2008, hlm. 2.

${ }^{3}$ Siti Soemarti Hartono, Penuntun dalam Mempelajari Hukum Perdata Belanda: Bagian Umum, University Press, Yogyakarta, 1992, hlm. 22. 
Novran Harisa, Asas Itikad Baik Dalam Perjanjian Arbitrasesebagai Metode Penyelesaian...

conflict of interest maupun kelalaian salah satu pihak dalam memenuhi isi perjanjian. Makin banyak dan luasnya kegiatan perdagangan, frekuensi terjadinya sengketa makin tinggi. Hal ini berarti makin banyak sengketa yang harus diselesaikan. Menurut Ali Achmad, sengketa adalah pertentangan antara dua pihak atau lebih yang berawal dari persepsi yang berbeda tentang suatu kepemilikan atau hak milik yang dapat menimbulkan akibat hukum antara kedua belah pihak (http://yuarta.blogspot.co.id). ${ }^{4}$

Sengketa bisnis membutuhkan penyelesaian yang efektif dan efisien agar tidak menimbulkan kerugian bagi para pihak. Dalam upaya penyelesaian sengketa inilah hukum dibutuhkan sebagai upaya memperoleh keadilan. Pada awalnya, penyelesaian sengketa dilakukan secara kekeluargaan. Apabila cara kekeluargaan tersebut tidak dapat memberi penyelesaian yang diharapkan, maka para pihak akan membawa sengketa tersebut ke pengadilan.

\footnotetext{
${ }^{4}$ http://yuarta.blogspot.co.id/2011/03/defi nisi-sengketa.html
}

Arbitrase merupakan salah satu metode penyelesaian sengketa bisnis di luar pengadilan. Penyelesaian sengketa melalui arbitrase berkembang pesat setelah abad ke-18 dengan lahirnya berbagai konvensi arbitrase internasional dan pusat arbitrase internasional maupun arbitrase nasional. Hampir setiap negara telah memiliki pusat arbitrase nasional (Sophar Maru Hutagalung, 2012:315). ${ }^{5}$ Indonesia juga memiliki pusat arbitrase nasional yang disebut dengan Badan Arbitrase Nasional Indonesia (BANI) yang didirikan oleh Kamar Dagang Indonesia (KADIN). ${ }^{6}$

Arbitrase semakin dikenal di Indonesia sejak diundangkannya Undang-Undang Nomor 30 Tahun 1999 tentang Arbitrase dan Alternatif Penyelesaian Sengketa (selanjutnya

\footnotetext{
${ }^{5}$ Sophar Maru Hutagalung, Praktik Peradilan Perdata dan Alternatif Penyelesaian Sengketa, Jakarta: Sinar Grafika, 2012, hlm. 315.

${ }^{6}$ Badan Arbitrase di berbagai negara, antara lain:

- Centre For Dispute Resolution (CEDR) di London;

- Australian Centre for International Commercial Arbitration (ACICA) di Australia;

- $\quad$ Singapore International Arbitration Centre (SIAC) di Singapura;

- Regional Centre for Arbitration di Kuala Lumpur;

- The International Commercial Arbitration Court di Rusia.
} 
disebut UUAAPS) pada tanggal 12 Agustus 1999. Kehadiran UUAAPS sekaligus memberikan dampak yang signifikan terhadap jumlah perkara bisnis yang diselesaikan melalui jalur arbitrase. Berdasarkan data dari Badan Arbitrase Nasional Indonesia (BANI), setelah diundangkannya UUAAPS, jumlah perkara yang masuk untuk ditangani BANI meningkat hingga mencapai $300 \%$ dibandingkan sebelum diundangkannya undang-undang tersebut (N. Krisnawenda, 2015:30). ${ }^{7}$

Sepanjang 2010 sampai 2014, BANI telah menangani sekitar 310 kasus sengketa bisnis. Menurut data yang dirilis BANI, dalam lima tahun terakhir, sengketa yang paling banyak terdaftar di BANI adalah sengketa di sektor konstruksi, porsinya mencapai $30,8 \%$ dari total sengketa. Sektor lainnya yang juga cukup sering ditangani BANI adalah dari sektor leasing, yakni mencapai

\footnotetext{
7 N. Krisnawenda, "32 Tahun Arbitrase BANI", Buletin Triwulan Arbitrase Indonesia, Nomor 8 Tahun 2015, Published by: BANI Arbitration Center, Jakarta, hlm. 30, diunduh pada www.baniarb.org pada tanggal 31 Maret 2016
}

20,8\%. Selebihnya merupakan perkara dari sektor pertambangan dan energi, investasi, keagenan, transportasi, asuransi, dan lain sebagainya (N. Krisnawenda, 2015:30). ${ }^{8}$

Menurut penulis, pembatalan putusan arbitrase pada hakikatnya menyebabkan arbitrase justru kehilangan keunggulannya. Sudargo Gautama menyatakan bahwa dengan adanya pembatalan putusan arbitrase, maka penyelesaian perkara melalui arbitrase justru akan membawa lebih banyak pengeluaran biaya dan sama sekali tidak akan lebih cepat dari pada langsung berperkara di pengadilan (Sudargo Gautama, 1979:3). ${ }^{9}$

Walaupun pembatalan putusan arbitrase dibenarkan oleh UUAAPS, dibutuhkan ketentuan yang jelas dan tegas serta konsistensi pengadilan dalam menentukan sebab-sebab pembatalan putusan arbitrase sehingga tidak akan mengganggu asas kepastian hukum dalam arbitrase. Dalam praktiknya, masih ada saja pihak yang merasa keberatan dan

\footnotetext{
${ }^{8}$ Ibid

${ }^{9}$ Sudargo Gautama, Arbitrase Dagang Internasional, Bandung: Alumni, 1979, hlm. 3 .
} 
tidak menerima putusan arbitrase dan mengajukan pembatalan terhadap putusan arbitrase ke pengadilan negeri. Bahkan ditemukan pula pengadilan yang menentang ketika arbitrase itu sendiri sudah menjatuhkan putusannya, seperti dalam kasus Bankers Trust Company melawan PT Mayora Indah Tbk. Pengadilan Negeri Jakarta Selatan tetap menerima gugatan PT. Mayora walaupun ada klausul arbitrase di dalamnya, dan menjatuhkan putusan No.46/Pdt.G/1999 tanggal 9 Desember 1999, yang memenangkan PT. Mayora.

$$
\text { Upaya-upaya penolakan }
$$

terhadap putusan arbitrase dilakukan melalui berbagai modus, seperti berusaha membatalkan perjanjian pokok, meminta pembatalan putusan arbitrase dengan berbagai alasan dan lain sebagainya. Padahal penggunaan arbitrase sebagai lembaga penyelesai sengketa merupakan pilihan yang telah disepakati para pihak dan dituangkan dalam perjanjian arbitrase. Kewenangan arbitrase tidak mungkin ada tanpa adanya perjanjian arbitrase yang dibuat oleh para pihak.
Arbitrase sebagai perjanjian diatur secara tegas dalam Pasal 1 angka (1) UUAAPS yang menyatakan bahwa:

"Arbitrase adalah cara penyelesaian suatu sengketa perdata di luar peradilan umum yang didasarkan perjanjian arbitrase yang dibuat secara tertulis oleh para pihak yang bersengketa".

Selanjutnya dalam Pasal 1 angka (3) UUAAPS dinyatakan bahwa:

"Perjanjian arbitrase adalah suatu kesepakatan berupa klausula arbitrase yang tercantum dalam suatu perjanjian tertulis yang dibuat para pihak sebelum timbul sengketa, atau suatu perjanjian arbitrase tersendiri yang dibuat para pihak setelah timbul sengketa".

Menurut penulis, adanya penolakan terhadap putusan arbitrase oleh para pihak dan inkonsistensi sikap pengadilan terhadap putusan arbitrase pada dasarnya dapat dipandang sebagai wujud ketiadaan itikad baik dalam menyikapi putusan arbitrase.

Itikad baik berkaitan erat dengan tata kehidupan bermasyarakat karena akan menyangkut terhadap 
Novran Harisa, Asas Itikad Baik Dalam Perjanjian Arbitrasesebagai Metode Penyelesaian...

kesadaran hukum masyarakat yang memerlukan pembinaan dan pengaturan (Djaja S. Meliala, 1987:1). ${ }^{10}$ Dalam lalu lintas hukum diharapkan sekali agar masyarakat selalu bertindak dengan dilandasi itikad baik, sehingga dapat menunjang usaha mewujudkan masyarakat adil dan makmur (Djaja

S. Meliala, 1987:1). ${ }^{11}$

Namun pada kenyataannya, terdapat sengketa transaksi bisnis yang telah diputus oleh badan arbitrase, justru menimbulkan kontroversi dan pelaksanaan putusannya masih berlarut-larut yang berujung pada pencitraan lemahnya kepastian hukum di Indonesia. Tanpa adanya itikad baik para pihak, putusan arbitrase sangat sulit untuk dapat segera dilaksanakan karena pihak yang tidak beritikad baik akan selalu mencari celah untuk membatalkan putusan arbitrase yang tidak sesuai dengan harapannya. Maka berdasarkan uraian yang telah dikemukakan terdahulu, penulis tertarik untuk mengadakan penelitian

${ }^{10}$ Djaja S. Meliala, Masalah Itikad Baik dalam KUHPerdata, Binacipta, Bandung: 1987 hlm. 1.

${ }^{11}$ Ibid lebih lanjut tentang Asas Itikad Baik dalam Perjanjian Arbitrase sebagai Metode Penyelesaian Sengketa.

Berdasarkan uraian diatas maka permasalahan dalam penelitian ini adalah bagaimana pengaturan itikad baik dalam perjanjian arbitrase sebagai metode penyelesaian sengketa Bisnis?

\section{B. HASIL DAN PEMBAHASAN}

Kajian atas hukum perjanjian tidak dapat dilepaskan dari keberadaan prinsip atau asas hukum yang mendasari bangunan hukum perjanjian. Bangunan hukum perjanjian yang dikatakan sebagai sistem hukum perjanjian memuat sejumlah asas hukum yang menjadi fundamen bagi bangunan hukum perjanjian. Paul Scholten menyebut asas hukum sebagai pernyataan mengenai hukum positif yang langsung menjadi jelas. Asas hukum itu ditemukan dalam hukum positif, dalam sistem peraturan-peraturan, keputusan-keputusan dan lembagalembaga dalam keseluruhannya, akan tetapi di samping yang positif itu asas hukum berisi penilaian susila, pemisahan yang baik dari yang buruk, 
Novran Harisa, Asas Itikad Baik Dalam Perjanjian Arbitrasesebagai Metode Penyelesaian...

yang menjadi landasan hukum (Paul

Scholten, 1992:89). ${ }^{12}$

Sistem hukum (Tatang

Amirin, 1986:4) ${ }^{13}$ perjanjian

dibangun berdasarkan asas-asas

hukum (Henry Campbell Black,

1991:828). ${ }^{14}$ Asas hukum berfungsi

sebagai pondasi yang memberikan

arah, tujuan serta penilaian

fundamental, mengandung nilai-nilai

dan tuntutan-tuntutan etis. Mariam

Darus mengemukakan bahwa sistem

\footnotetext{
${ }^{12}$ Paul Scholten, Mr. C Asser: Penuntun Dalam Mempelajari Hukum Perdata Belanda, terjemahan Siti Soemarti Hartono, Gadjah Mada University Press, Yogyakarta, 1992, hlm. 89.

${ }^{13}$ Teori sistem merupakan aliran yang paling penting dalam positivisme hukum, yang intinya bahwa hukum adalah suatu stelsel dari aturan yang berkaitan satu sama lain secara organis, secara piramida dari norma-norma yang terbentuk secara hierarki. Lihat N.E. Algra dan K.Van Duyvendijk, Mula Hukum, Jakarta: Binacipta, 1983, hlm. 139. Mengenai pengertian sistem, William A Schrode dan Voich menjelaskan bahwa: the term "system" has two important connotations. The first is the notion of system as an entity or thing which has particular order or structural arrangement of its parts. The second is the notion of system as a plan, methode, device, or procedure for accomplishing something . Lihat Tatang Amirin, Pokok-Pokok Teori Sistem, Jakarta: Rajawali, 1986, hlm. 4.

14 Menurut Henry Campbell Black, "principle is the fundamental of truth or doctrine, as of law, a comprehensive law or doctrine which furnishes a basic or origin for others", Henry Campbell Black, Black's Law Dictionary, St. Paul Minn, West Group,1991, hlm. 828.
}

hukum merupakan kumpulan asasasas hukum yang terpadu di atas mana dibangun tertib hukum (Mariam Darus Badruzzaman, 1990:5). ${ }^{15}$ Pandangan ini menunjukkan arti sistem hukum dari segi substantif. Dilihat dari segi substantif, asas hukum perjanjian adalah suatu pikiran mendasar tentang kebenaran untuk menopang norma hukum dan menjadi elemen yuridis dari suatu sistem hukum perjanjian. Dalam suatu sistem yang baik, tidak boleh terjadi suatu pertentangan atau perbenturan antara bagian-bagian tersebut dan juga tidak boleh terjadi suatu duplikasi atau tumpang tindih (overlapping) di antara bagian-bagian itu (Tan Kamello, 2006:6). ${ }^{16}$

15 Mariam Darus Badruzzaman, Hukum Benda Nasional, Bandung: Alumni, 1990, hlm.5. Sebagai suatu sistem, hukum terdiri dari sub-sub sistem yang satu sama lain berkaitan dalam hubungan yang seimbang,dan serasi tidak tumpang tindih,tidak berbenturan karena asasasasnya yang terpadu. Asas-asas yang terdapat dalam hukum perdata harus senada, seirama dengan asas yang terdapat dalam Hukum Nasional, demikian juga dengan asas-asas hukum perjanjian harus senada dengan asas-asas hukum perdata.

${ }^{16}$ Tan Kamello, "Karakter Hukum Perdata dalam Fungsi Perbankan melalui Hubungan antara Bank dengan Nasabah", Pidato Pengukuhan Jabatan Guru Besar Tetap dalam Bidang Ilmu Hukum Perdata pada Fakultas Hukum, 2 September 2006, 
Novran Harisa, Asas Itikad Baik Dalam Perjanjian Arbitrasesebagai Metode Penyelesaian...

Kajian atas hukum perjanjian juga tidak dapat dilepaskan dari keberadaan prinsip atau asas hukum yang mendasari bangunan hukum kontrak. Bangunan hukum kontrak yang dikatakan sebagai sistem hukum kontrak memuat sejumlah asas hukum yang menjadi fundamen bagi bangunan hukum kontrak. Paul Scholten menyebut asas hukum sebagai pernyataan mengenai hukum positif yang langsung menjadi jelas. Asas hukum itu ditemukan dalam hukum positif, dalam sistem peraturan-peraturan, keputusankeputusan dan lembaga-lembaga

Diucapkan di Hadapan Rapat Senat Terbuka Universitas Sumatera Utara, Gelanggang Mahasiswa Kampus USU, hlm. 6. Subekti berpendapat bahwa: "sistem hukum adalah suatu susunan atau tataan yang teratur, suatu keseluruhan yang terdiri dari atas bagian-bagian yang berkaitan satu sama lain, tersusun menurut suatu rencana atau pola hasil dari suatu penulisan untuk mencapai suatu tujuan". Setiap sistem mengandung beberapa asas yang menjadi pedoman dalam pembentukannya dan dapat dikatakan bahwa suatu sistem adalah tidak terlepas dari asas-asas yang mendukungnya dengan demikian sifat sistem itu menyeluruh dan berstruktur yang keseluruhan komponenkomponennya bekerja sama dalam hubungan fungsional. Kalau dikatakan bahwa hukum itu sebagai suatu sistem, artinya suatu susunan atau tataan teratur dati aturan-aturan hidup. Misalnya dalam hukum perdata sebagai sistem hukum positif. dalam keseluruhannya, akan tetapi disamping yang positif itu asas hukum berisi penilaian susila, pemisahan yang baik dari yang buruk, yang menjadi landasan hukum (J.J.H.

Bruggink, 1999:119). ${ }^{17}$

Satjipto Rahardjo menyatakan bahwa asas hukum, bukan peraturan hukum. Namun, tidak ada hukum yang bisa dipahami tanpa mengetahui asas-asas hukum yang ada di dalamnya, karena asas hukum ini memberi makna etis kepada peraturan-peraturan hukum dan tata hukum. Asas hukum adalah unsur yang penting dan pokok dari peraturan hukum. Satjipto selanjutnya mengibaratkan asas hukum sebagai jantung peraturan hukum. Pandangan ini didasarkan atas dasar bahwa asas hukum merupakan "landasan yang paling luas" bagi lahirnya sebuah peraturan hukum. Ini berarti bahwa peraturan-peraturan hukum itu pada akhirnya bisa dikembalikan kepada asas hukum.Asas hukum juga layak disebut sebagai" alasan" atau merupakan ratio legis dari peraturan

\footnotetext{
${ }^{17}$ J.J.H. Bruggink, Refleksi Tentang Hukum, Terjemahan B. Arief Sidharta, Bandung, Citra Aditya Bakti, 1999, hlm. 119.
} 
Novran Harisa, Asas Itikad Baik Dalam Perjanjian Arbitrasesebagai Metode Penyelesaian...

hukum. Asas mengandung nilai-nilai dan tuntutan-tuntutan etis, oleh karena itu maka asas hukum diibaratkan sebagai jembatan antara peraturan-peraturan hukum dengan cita-cita sosial dan pandangan etis masyarakatnya (Satjipto Rahardjo, 2006:45). ${ }^{18}$

Asas hukum adalah suatu pikiran yang bersifat umum dan abstrak yang melatarbelakangi hukum positif. Dengan demikian asas hukum tersebut tidak tertuang dalam hukum yang konkrit. Pengertian tersebut dapat ditarik dari pendapat Sudikno Mertokusumo, yang memberi penjelasan sebagai berikut: Pengertian asas hukum atau prinsip hukum bukanlah peraturan hukum konkrit, melainkan merupakan pikiran dasar yang umum sifatnya atau merupakan latar belakang dari peraturan yang konkrit yang terdapat dalam dan di belakang setiap sistem hukum yang terjelma dalam peraturan perundang-undangan dan putusan hakim yang merupakan hukum positif dan dapat dikemukakan dengan mencari sifat-sifat umum dalam

\footnotetext{
18 Satjipto Rahardjo, Ilmu Hukum, (Cetakan Keenam), Bandung: Citra Aditya Bakti, 2006, hlm. 45.
}

peraturan konkrit terebut (Sudikno Mertokusumo, 1986:33). ${ }^{19}$

Asas hukum berfungsi sebagai fondasi yang memberikan arah, tujuan serta penilaian fundamental, mengandung nilai-nilai dan tuntutan etis. Bahkan dalam suatu mata rantai sistem, asas, norma dan tujuan hukum berfungsi sebagai pedoman dan ukuran atau kriteria bagi perilaku manusia. Melalui asas hukum, norma hukum berubah sifatnya menjadi bagian suatu tatanan etis yang sesuai dengan nilai kemasyarakatan. Pemahaman tentang kebenaran suatu norma hukum dapat ditelusuri dari ratio legis-nya. Meskipun asas hukum bukan norma hukum, namun tidak ada norma yang dapat dipahami tanpa mengetahui asas-asas hukum yang terdapat di dalamnya (Satjipto Rahardjo, 2006:46). ${ }^{20}$

Dalam hal aturan-aturan hukum yang ada tidak dapat menetapkan mengenai hukum sesuatu atau memecahkan persoalan, akan dibutuhkan bantuan asas-asas hukum untuk memberikan makna terhadap

19 Sudikno Mertokusumo, Mengenal Hukum (Suatu Pengantar), Liberty, Yogyakarta, 1986, hlm.33.

${ }^{20}$ Satjipto Rahardjo, Op.cit., hlm. 46 
Novran Harisa, Asas Itikad Baik Dalam Perjanjian Arbitrasesebagai Metode Penyelesaian...

aturan-aturan hukum yang sudah ada. Setiap kasus (hukum) harus dipecahkan dengan melakukan penafsiran sebagai semacam pelengkap. Disinilah menafsirkan aturan hukum itu bukanlah berarti menafsirkan aturan dalam arti conventional interpretation, melainkan suatu constructive interpretation (Satjipto Rahardjo, 2006:80-81). ${ }^{21}$

Asas hukum berfungsi baik di dalam maupun di belakang sistem hukum positif. Asas hukum itu dapat berfungsi demikian karena berisi ukuran nilai. Sebagai kaidah penilaian, asas hukum itu mewujudkan kaidah hukum tertinggi dari suatu sistem hukum positif. Itu sebabnya asas-asas hukum itu adalah fondasi dari sistem tersebut. Asas hukum itu terlalu umum untuk dapat berperan sebagai pedoman bagi perbuatan. Karena itu, asas hukum harus dikonkritisasikan. Pembentuk undang-undang membentuk aturan hukum, yang di dalamnya ia merumuskan kaidah perilaku. Selanjutnya konkritisasi dalam kaidah perilaku ini terjadi melalui

\footnotetext{
${ }^{21}$ Ibid., hlm. 80-81.
}

generalisasi putusan-putusan hakim. Jika pengkonkritisasian telah terjadi dan sudah ditetapkan (terbentuk) aturan-aturan hukum positif dan putusan-putusan, maka asas hukum tetap memiliki sifat sebagai kaidah penilaian. Dengan itu maka fungsi kedua asas hukum tampil ke permukaan. Ukuran nilai yang diberikan asas hukum itu sulit untuk diwujudkan secara sepenuhnya. Dengan itu, asas hukum dapat tetap berada berhadapan dengan sistem hukum positif dan berfungsi sebagai batu-uji kritis (kritische toetssteen) (J.J.H. Bruggink, 1999:132). ${ }^{22}$

J. Gijssels dalam artikelnya juga mengakui kedua fungsi tersebut, tetapi ia berpendapat bahwa hanya asas yang menjalankan fungsi yang pertama adalah asas hukum, karena hanya asas ini yang termasuk dalam hukum positif. Asas-asas yang menjalankan fungsi yang kedua menurut pendapatnya berkenaan dengan kaidah-kaidah etis dan ideaidea filsafat negara, bukan tentang asas-asas hukum. Dengan demikian dapat disimpulkan bahwa asas hukum mengemban fungsi ganda: sebagai

\footnotetext{
${ }^{22}$ Bruggink, Op.Cit., hlm. 132.
} 
fondasi dari sistem hukum positif dan sebagai batu uji kritis terhadap sistem hukum positif.

Beranjak dari pandangan di atas dapat dipahami bahwa asas-asas hukum bertujuan untuk memberikan arahan yang layak /pantas (menurut hukum rechtmatig) dalam hal menggunakan atau menerapkan aturan-aturan hukum. Asas-asas hukum tersebut berfungsi sebagai pedoman atau arahan orientasi agar suatu hukum dapat dan boleh dijalankan (J.J.H. Bruggink, 1999:82-83). ${ }^{23}$ Asas-asas hukum tersebut tidak hanya akan berguna sebagai pedoman ketika menghadapi kasus-kasus sulit, tetapi juga pada umumnya berguna dalam hal menerapkan aturan. Asas-asas hukum membentuk konteks interpretasi yang niscaya dari aturan-aturan hukum. Mengenai fungsi interpretasi tersebut, asas-asas hukum demi kepentingan aturan-aturan hukum mensyaratkan pelibatan moral dan susila. Meskipun aturan-aturan (hukum) harus diterangkan beranjak dari latar belakang asas-asas hukum niscaya terkonkretisasi ke dalam aturan-

\footnotetext{
${ }^{23}$ Ibid., hlm. 82-83.
}

aturan, satu persoalan lagi yang perlu dijelaskan, yakni bagaimana keberadaan asas-asas hukum dalam kaitannya dengan hukum positif. Asas-asas hukum hanya memiliki keberlakuan jika objek yang terkait dengannya dimunculkan dalam bentuknya yang terbaik. Oleh karena itulah, menurut R. Dworkin, keberadaan asas-asas hukum bukanlah merupakan keberadaan sosial, melainkan semata-mata konstruktif (J.J.H. Bruggink, 1999:85). ${ }^{24}$

Keberlakuan asas-asas hukum secara formil dilandaskan pada penerimaannya oleh forum yuridis sehingga asas-asas hukum memperoleh suatu keberlakuan formil. Dalam pembentukan peraturan perundang-undangan yang berlaku saat ini terdapat kecenderungan untuk meletakkan asas-asas hukum atau asas-asas pembentukan peraturan perundangundangan tersebut di dalam salah satu pasal-pasal awal, atau dalam Bab Ketentuan Umum seperti dirumuskan dalam Pasal 5 dan Pasal 6 UndangUndang Nomor 12 Tahun 2011

\footnotetext{
${ }^{24}$ Ibid., hlm. 85.
} 
Novran Harisa, Asas Itikad Baik Dalam Perjanjian Arbitrasesebagai Metode Penyelesaian...

tentang Pembentukan Peraturan Perundang-undangan. Dalam kedua pasal tersebut, asas hukum telah ditetapkan menjadi suatu rumusan norma hukum.

Keberlakuan formil dari asas hukum juga muncul dalam bentuk putusan hakim yang menguji asasasas hukum tersebut pada undangundang atau kebiasaan yang hendak diaplikasikan terhadap kasus tertentu yang dihadapinya. Baik aturan maupun asas hukum dapat kehilangan daya keberlakuannya. Daya keberlakuan aturan hukum akan hilang ketika aturan hukum itu tidak digunakan lagi. Sedangkan daya keberlakuan asas hukum akan hilang jika (tata) yang terungkap di dalamnya telah berubah. Di samping itu terdapat perbedaan di antara asas hukum dengan aturan hukum. Asas hukum dapat dikatakan memiliki peran tidak langsung, sementara aturan hukum berperan secara langsung dalam putusan hukum.

Asas hukum bukanlah peraturan hukum, akan tetapi tidak ada hukum yang bisa dipahami tanpa mengetahui asas-asas hukum yang ada di dalamnya. Oleh karena itu untuk memahami hukum suatu bangsa tidak bisa hanya melihat kepada peraturanperaturan hukumnya saja, melainkan harus menggali sampai kepada asasasas hukumnya. Asas hukum inilah yang memberi makna etis kepada peraturan-peraturan hukum serta tata hokum (Satjipto Rahardjo, 2006:8081). ${ }^{25}$

Hukum perjanjian, dalam perkembangannya juga tidak terlepas dari eksistensi dan pengandalan asasasas hukum. Kedudukan asas hukum merupakan dasar pokok dalam memperkuat kokohnya bangunan hukum kontrak. Beberapa asas pokok dalam hukum kontrak adalah asas konsensualitas, asas kebebasan berkontrak dan asas itikad baik. Ketiga asas ini menjadi pilar utama tegaknya bangunan hukum kontrak. Asas konsensualitas (consensus) menentukan momentum lahir dan mengikatnya kontrak, yakni saat tercapainya kesepakatan atau persesuaian kehendak terhadap halhal pokok dari kontrak. Bila para pihak telah mencapai persesuaian kehendak, kontrak yang dibuat menjadi mengikat sebagai undang-

\footnotetext{
${ }^{25}$ Satjipto Rahardjo, Loc.Cit.
} 
Novran Harisa, Asas Itikad Baik Dalam Perjanjian Arbitrasesebagai Metode Penyelesaian...

undang bagi mereka yang berbunyi "perjanjian harus memberikan kesepakatan. Karena itu asas kekuatan mengikat kontrak sebagai undang-undang pada dasarnya merupakan konsekuensi dan implementasi dari asas konsensualitas. Akibatnya, kontrak tidak dapat ditarik kembali, kecuali dengan sepakat kedua belah pihak. ${ }^{26}$

Asas kekuatan mengikatnya kontrak menjadi dasar penting di dalam hukum bahwa orang harus mematuhi janji. Dengan perkataan lain, asas inilah yang menjadi landasan bahwa para pihak di dalam kontrak terikat atau wajib melaksanakan perjanjian. Secara yuridis asas ini diakui keberadaannya oleh Pasal 1338 ayat (1) Kitab Undang-Undang Hukum Perdata (KUHPerdata). Pasal ini menyatakan bahwa semua perjanjian yang dibuat secara sah berlaku sebagai undangundang bagi yang membuatnya. ${ }^{27}$

Sementara itu, dalam sistem civil law di Indonesia, itikad baik dalam hubungan kontraktual diatur melalui Buku ke-III KUHPerdata yakni Pasal 1338 ayat (3) yang

\footnotetext{
${ }^{26}$ Pasal 1338 ayat (2) KUHPerdata

${ }^{27}$ Ibid, hlm. 38
}

dilaksanakan dengan itikad baik." Makna itikad baik ini dikaitkan dengan Pasal 1339 KUHPerdata yang menyebutkan "Suatu perjanjian tidak hanya mengikat untuk hal-hal yang dengan tegas dinyatakan di dalamnya, tetapi juga untuk segala sesuatu yang menurut sifat perjanjian diharuskan oleh kepatutan, kebiasaan atau Undang-Undang".

Kaidah normatif tentang itikad baik dalam Pasal 1338 ayat (3) jo. Pasal 1339 KUHPerdata pada dasarnya mengatur pelaksanaan kontrak tidak semata-mata berdasarkan apa yang diperjanjikan secara eksplisit di dalam kontrak, akan tetapi harus memperhatikan kepatutan, kebiasaan dan undangundang.. Menurut Yahya Harahap, pelaksanaan kontrak secara patut berarti melaksanakan kewajiban menurut yang sepatutnya, serasi dan layak menurut yang seharusnya sesuai dengan ketentuan yang telah disepakati dalam kontrak (Yahya Harahap, 1992:57). ${ }^{28}$

\footnotetext{
28 Yahya Harahap, Segi-Segi Hukum Perjanjian, Alumni, Bandung, 1992, hlm. 57.
} 
Novran Harisa, Asas Itikad Baik Dalam Perjanjian Arbitrasesebagai Metode Penyelesaian...

Seorang pembeli barang yang beritikad baik adalah orang yang membeli barang dengan penuh kepercayaan bahwa si penjual sungguh-sungguh pemilik dari barang yang dibelinya tersebut. Ia sama sekali tidak mengetahui jika seandainya ia membeli dari orang yang tidak berhak. Itu mengapa ia disebut sebagai seorang pembeli yang jujur. Dalam anasir ini, itikad baik memiliki arti kejujuran atau bersih. ${ }^{29}$

Dalam bahasa Indonesia, itikad baik dalam arti subyektif disebut kejujuran. Hal itu terdapat dalam pasal 530 KUHP Perdata dan seterusnya yang mengatur mengenai kedudukan berkuasa (bezit). Itikad baik dalam arti subyektif ini merupakan sikap batin atau suatu keadaan jiwa. Berdasarkan pasal 1338 (3) KUH Perdata, kejujuran (itikad baik) tidak terletak pada keadaan jiwa manusia, akan tetapi terletak pada tindakan yang dilakukan oleh kedua belah pihak dalam melaksanakan janji, jadi kejujuran disini bersifat dinamis. Kejujuran dalam arti dinamis atau kepatutan ini berakar pada sifat peranan hukum pada

\footnotetext{
${ }^{29}$ Ridwan Khairandy, Op.Cit, hlm. 181.
}

umumnya, yaitu usaha untuk mengadakan keseimbangan dari berbagai kepentingan yang ada dalam masyarakat

Beranjak dari pemahaman tentang itikad baik objektif, maka pelaksanaan perjanjian tidak hanya tergantung pada klausula yang telah dirumuskan tetapi juga harus dilakukan secara patut dan masuk akal (redelijkheid en billijkheid). Ini didasarkan dari suatu sifat peraturan hukum pada umumnya, yaitu usaha untuk mengadakan keseimbangan berbagai kepentingan yang ada dalam masyarakat. $^{30}$ Di sini, itikad baik objektif dalam arti kepatutan dan masuk akal (redelijkheid en billijkheid) sebagai penguji jika salah satu pihak mengatakan sudah bertindak jujur namun ternyata ia tidak bertindak secara tidak patut (Agus Yudha Hernoko, 2008:124). ${ }^{31}$

Acuan itikad baik dalam hukum Romawi tersebut sejalan dengan yang dikemukakan Ulpianus "Juris praecepta sunt haec; honeste vivere, alterum non laedere, suum cuique tribuere" yang berarti "Semboyan

\footnotetext{
${ }^{30}$ Herlien Budiono, Op.Cit., hlm. 322.

31 Agus Yudha Hernoko, Op.Cit., hlm. 124
} 
Novran Harisa, Asas Itikad Baik Dalam Perjanjian Arbitrasesebagai Metode Penyelesaian...

hukum adalah hidup secara jujur, tidak merugikan orang lain; dan memberikan orang lain haknya" (Munir Fuady, 2005:2). ${ }^{32}$ Peneliti berpandangan bahwa itikad baik memang terletak pada jiwa (batin) seseorang, akan tetapi itikad baik tersebut dapat dinilai dari sikap (perilaku) yang ditunjukkan seseorang secara lahiriah. Dihubungkan dengan arbitrase sebagai metode penyelesaian sengketa, peneliti berpendapat bahwa pengaturan itikad baik dalam Undang-Undang Arbitrase dapat dirumuskan secara limitatif berdasarkan kriteria-kriteria yang telah dikemukakan oleh para ahli maupun perundang-undangan.

Pengaturan secara limitatif tersebut memang tidak mungkin mampu memberikan pengertian yang sempurna tentang itikad baik, akan tetapi setidaknya dapat menjadi acuan dalam menilai tindakan para pihak dalam pelaksanaan perjanjian arbitrase.

32 Munir Fuady, Perbuatan Melawan Hukum (Pendekatan Kontemporer), PT Citra Aditya Bakti, Bandung, Cet. II, 2005, hlm. 2.
Pengaturan itikad baik dalam UUAAPS sangatlah tidak memadai karena hanya menyebutkan "itikad baik" tanpa sedikitpun memberi pengaturan lebih lanjut tentang itikad baik yang dimaksud. Pasal 6 ayat (1) Undang-Undang Nomor 30 Tahun 1999 menyebutkan, "Sengketa atau beda pendapat perdata dapat diselesaikan oleh para pihak melalui alternatif penyelesaian sengketa yang didasarkan pada itikad baik dengan mengesampingkan penyelesaian secara litigasi di Pengadilan Negeri”.

Penulis berpendapat bahwa rumusan itikad baik dalam perjanjian arbitrase setidaknya harus merumuskan standar minimal pengertian itikad baik. Pengaturan itikad baik dalam perjanjian arbitrase harus dirumuskan sebagai "sikap atau perilaku berpegang teguh pada perjanjian untuk memberikan kepada lawan janji apa yang menjadi haknya dan tidak mencari-cari celah untuk melepaskan diri dari apa yang telah diperjanjikan berdasarkan kepatutan dan kerasionalan.

Dengan adanya pengaturan itikad baik secara limitatif tersebut, hakim mempunyai standar dalam 
menilai ada tidaknya itikad buruk dari penggugat yang ingin membatalkan putusan arbitrase. Jika permohonan pembatalan putusan arbitrase dilakukan dengan melakukan tipu daya, kelicikan, mengada-ngada dan melakukan cara-cara yang tidak patut dalam pandangan hukum dan sosial, maka hakim harus menolak permohonan tersebut sehingga putusan arbitrase dapat segera dilaksanakan.

\section{C.SIMPULAN}

1. Implementasi koordinasi penyidikan tindak pidana korupsi antar lembaga penegak hukum belum berjalan maksimal karena adanya ego sektoral yang memicu disintegrasi dan melahirkan rivalitas antar institusi penegak hukum serta dipengaruhi kualitas teknis dan taktis aparat penyidik. Lemahnya koordinasi penyidikan mengakibatkan terjadinya tarik-menarik kewenangan dalam penyidikan tindak pidana korupsi terutama yang melibatkan personel Kepolisian, Kejaksaan dan KPK yang menciptakan situasi disharmonis antar lembaga penegak hukum dan berujung terjadinya pelambatan penyelesaian perkara tindak pidana korupsi sehingga implementasi koordinasi penyidikan terhadap tindak pidana korupsi belum sesuai dengan asas peradilan cepat, sederhana dan biaya ringan yang mensyaratkan adanya sinkronisasi atau keserempakan dan keselarasan dalam hubungan antar penegak hukum (structural syncronization).

2. Penyidikan tindak pidana korupsi selama ini hanya memberi ruang koordinasi kepada penyidik dan penuntut umum tetapi tidak dengan dengan hakim Tipikor. Ketiadaan koordinasi dan kerjasama antara penyidik, penuntut umum dengan hakim dalam realitasnya selalu memunculkan perbedaan pandangan pada tahap pemeriksaan di persidangan dan melahirkan putusan yang jauh dari tuntutan. Padahal untuk 
Novran Harisa, Asas Itikad Baik Dalam Perjanjian Arbitrasesebagai Metode Penyelesaian...

mewujudkan sinkronisasi dan keserempakan sistem peradilan pidana setiap institusi penegak hukum semestinya diberikan ruang agar saling berkoordinasi termasuk dengan hakim Tipikor. Koordinasi antara penyidik, penuntut umum dengan hakim Tipikor memerlukan pengaturan dalam Undang-undang tersendiri didukung dengan peraturan yang bersifat teknis. Pengaturan Koordinasi dalam Undangundang bukan untuk mempengaruhi atau mengintervensi kekuasaan kehakiman yang mandiri (independency judiciary), melainkan untuk membangun persamaan persepsi antar lembaga penegak hukum dari hulu sampai ke hilir untuk tujuan sinkronisasi sistem peradilan pidana yang sinergis dan terpadu (integrated criminal justice system).

\section{SARAN}

1. Pelaksanaan koordinasi penyidikan tindak pidana korupsi mengalami persoalan karena adanya situasi disharmonis dan rivalitas antar lembaga penegak hukum yang menghambat pecepatan penyelesaian kasus. Oleh karena itu, disarankan kepada penegak hukum Kepolisian, Kejaksaan dan KPK sebaiknya mengesampingkan ego sektoral agar koordinasi berjalan baik dan menciptakan keserempakan, diperkuat dengan adanya pelatihanpelatihan khusus kepada para penyidik, penuntut umum maupun hakim untuk meningkatkan kualitas, teknik dan manajemen peradilan yang memprioritaskan percepatan penyelesaian dan pengurangan tunggakan perkara tindak pidana korupsi untuk mencapai asas peradilan cepat, sederhana dan biaya ringan.

2. Untuk menciptakan sinkronisasi dan keserempakan antar lembaga penegak hukum Kepolisian, Kejaksaan, KPK dan hakim Tipikor memerlukan koordinasi yang simultan dan 
sinergis dari hulur sampai ke hilir. Untuk itu disarankan kepada lembaga legislatif (DPR) untuk membuka ruang koordinasi antara penyidik, penuntut umum dengan hakim Tipikor melalui pembentukan Undang-undang yang mengatur tentang koordinasi antar lembaga penegak hukum atau diintegrasikan dalam RUU KUHAP mendatang dan ditindaklanjuti dengan penerbitan SEMA oleh Mahkamah Agung sebagai petunjuk dan pedoman bagi para hakim untuk berkoordinasi dengan penyidik dan penuntut umum dalam menilai kasus tindak pidana korupsi, sehingga melalui koordinasi diharapkan dapat mendorong terwujudnya sistem peradilan pidana terpadu (integrated criminal justice system).

\section{DAFTAR PUSTAKA}

Agus Yudha Hernoko, Hukum Perjanjian:Asas

Proporsionalitas dalam Kontrak Komersial, LaksBang Mediatama, Yogyakarta, 2008.
Djaja S. Meliala, Masalah Itikad Baik dalam KUHPerdata, Binacipta, Bandung, 1987.

Henry Campbell Black, Black's Law Dictionary, St. Paul Minn, West Group,1991.

http://yuarta.blogspot.co.id/2011/03/d efinisi-sengketa.html

J. J. H. Bruggink, Refleksi Tentang Hukum, Terjemahan B. Arief Sidharta, Bandung, Citra Aditya Bakti, 1999.

Mariam Darus Badruzzaman, Hukum Benda Nasional, Bandung: Alumni, 1990.

Munir Fuady, Perbuatan Melawan Hukum (Pendekatan Kontemporer), PT Citra Aditya Bakti, Bandung, Cet. II, 2005.

N. E. Algra dan K.Van Duyvendijk, Mula Hukum, Jakarta, Binacipta, 1983.

N. Krisnawenda, "32 Tahun Arbitrase BANI", Buletin Triwulan Arbitrase Indonesia, Nomor 8 Tahun 2015, Published by: BANI Arbitration Center, Jakarta, diunduh pada www.baniarb.org

Paul Scholten, $M r$. C Asser: Penuntun Dalam Mempelajari Hukum Perdata Belanda, terjemahan Siti Soemarti Hartono, Gadjah Mada University Press, Yogyakarta, 1992.

R. Subekti, Hukum Perjanjian, PT. Intermassa, Jakarta, 2002. 
Novran Harisa, Asas Itikad Baik Dalam Perjanjian Arbitrasesebagai Metode Penyelesaian...

Satjipto Rahardjo, Ilmu Hukum,

(Cetakan Keenam), Bandung:

Citra Aditya Bakti, 2006.

Siti Soemarti Hartono, Penuntun dalam Mempelajari Hukum Perdata Belanda: Bagian Umum, University Press, Yogyakarta, 1992.

Sophar Maru Hutagalung, Praktik Peradilan Perdata dan Alternatif Penyelesaian Sengketa, Jakarta: Sinar Grafika, 2012.

Sudargo Gautama, Arbitrase Dagang Internasional, Bandung: Alumni, 1979.

Sudikno Mertokusumo, Mengenal Hukum (Suatu Pengantar), Liberty, Yogyakarta, 1986.

Tan Kamello, "Karakter Hukum Perdata dalam Fungsi Perbankan melalui Hubungan antara Bank dengan Nasabah", Pidato Pengukuhan Jabatan Guru Besar Tetap dalam Bidang Ilmu Hukum Perdata pada Fakultas Hukum, 2 September 2006.

Tatang Amirin, Pokok-Pokok Teori Sistem, Jakarta, Rajawali, 1986.

Yahya Harahap, Segi-Segi Hukum Perjanjian, Alumni, Bandung, 1992. 